\title{
Analisis Faktor Risiko Yang Mempengaruhi Financial Statement Fraud: Prespektif Diamond Fraud Theory
}

\author{
${ }^{1 *}$ Titi Purbo Sari, ${ }^{2}$ Dian Indriana Tri Lestari \\ ${ }^{1,2}$ Fakultas Ekonomi Universitas Semarang, Indonesia \\ *Email korenpondensi: titi@usm.ac.id
}

\begin{abstract}
The increasing number of cases of accounting scandals in the world has caused various parties to speculate that management has committed fraud in the financial statements. Many cheating risk factor assessments adopted several auditing standards regarding fraud detection (ie SAS No.82, ISA 240, and SAS No.99), and referred to the Fraud Triangle theory. Wolfe and Hermanson (2004), improve the detection of fraud triangle fraud by considering the fourth element, namely capability and is known as Diamond Fraud. This study aims to examine Fraud Diamond's influence on financial statement fraud. The sample of this study were 29 companies in the banking subsector listed on the Indonesia Stock Exchange for the 2014-2018 period using 128 annual reports. The data analysis method used is the method of multiple linear regression analysis. The independent variable in this study consisted of financial stability, external pressure, personal financial needs, nature of industry, ineffective monitoring, auditor opinion, change in auditor, total accrual, and change in director. While the dependent variable in this study is Fraud's Financial Statement which is proxied by the value of discretionary accruals from the Modified Jones Model. The results of the study indicate that the personal financial need and total accrual variables that have a positive and significant effect on financial statemanet fraud. The financial stability, external pressure, financial targets, nature of industry, ineffective monitoring, auditor opinion, change in auditor, and change in director cannot be used to detect fraudulent financial statements.
\end{abstract}

Keywords: Discretionary Accrual, Financial Statement Fraud, Fraud Diamond.

Saran sitasi: Sari, T. P., \& Lestari, D. I. T. (2020). Analisis Faktor Risiko Yang Mempengaruhi Financial Statement Fraud: Prespektif Diamond Fraud Theory. Jurnal Akuntansi dan Pajak, 20(2), 109-125. doi: http://dx.doi.org/10.29040/jap.v20i2.618

DOI: http://dx.doi.org/10.29040/jap.v20i2.618

\section{Pendahuluan}

Laporan keuangan merupakan instrumen penting dalam aktivitas perusahaan yang berisi catatan informasi akuntansi perusahaan pada suatu periode akuntansi dan mencerminkan kondisi keuangan perusahaan. Laporan keuangan menjadi produk utama dalam akuntansi karena menyajikan informasi-informasi yang dibutuhkan oleh para pengguna laporan keuangan sebagai pertanggungjawaban manajemen atas kinerja perusahaan dan untuk menilai earning power perusahaan di masa yang akan datang.

Oleh karena itu, laporan keuangan harus disajikan secara akurat dan relevan, sehingga informasi-informasi dalam laporan keuangan dapat digunakan untuk pengambilan keputusan oleh pihak- pihak yang berkepentingan. Pada kenyataannya informasi yang disajikan dalam laporan keuangan tersebut sering terjadi penyimpangan karena tidak relevan dan mengandung salah saji, sehingga mengakibatkan para pengguna laporan keuangan tidak dapat mengambil keputusan ekonomi karena hasil analisis yang tidak sesuai (Martyanta dan Daljono, 2013).

Hasil penelitian Association of Certified Fraud Examiners (ACFE) Global menunjukkan bahwa setiap tahun rata-rata 5\% dari pendapatan organisasi menjadi korban fraud. Menurut ACFE pada tahun 2016 total kerugian yang diakibatkan oleh fraud mencapai USD 6,3 miliar dengan rata-rata kerugian per kasus mencapai lebih dari USD 2,7 juta. Kecurangan yang paling banyak terjadi adalah penyalahgunaan aset, kemudian disusul fraud yang 


\section{Jurnal Akuntansi dan Pajak, 20(02), 2019, 110}

berbentuk korupsi. Selanjutnya, kasus yang paling sedikit terjadi adalah kecurangan laporan keuangan (fraudulent financial statement) yaitu sebesar kurang dari $10 \%$ dari keseluruhan kasus fraud, namun dampak kerugian yang ditimbulkan sangat besar dibandingkan jenis fraud lain. Hal ini menyebabkan informasi yang terkandung di dalam laporan keuangan tidak valid dan dapat menyesatkan pengguna laporan keuangan dalam mengambil keputusan.

Kasus mengenai financial statement fraud telah banyak terjadi, seperti di Amerika kasus Enron pada Desember 2001 berdampak sangat luas terhadap keuangan pasar global. Kasus tersebut melibatkan akuntan publik dalam melakukan kecurangan laporan keuangannya, dengan melakukan window dreesing, serta menyembunyikan hutang-hutangnya dengan tehnik off-balance sheet (Soltani, 2014). Di Jepang, kasus kecurangan yang melibatkan 3 direksi PT. Toshiba yang menggelembungkan laba usaha Toshiba sebesar $¥ 151,8$ miliar (setara dengan $\mathrm{Rp}$ 15,85 triliun), sehingga menyebabkan harga saham Toshiba turun sekitar $20 \%$ atas tindakan direksi tersebut. Pada perusahaan perbankan di Indonesia terdapat beberapa kasus, antara lain tahun 2003 Bank Lippo memanipulasi laporan keuangan periode 2002, kemudian tahun 2011 terjadi pembobolan BRI Tarmini Square, Bank Mandiri, BNI Cabang Depok, BPR Pundi Artha Sejahtera, Bank Danamon dan penggelapan dana nasabah Bank Panin. Tahun 2012 terjadi pembobolan nasabah premium di Citibank yang melibatkan Malinda Dee, kemudian pada tahun 2018 Bank Bukopin diduga melakukan manipulasi data kartu kredit dengan merevisi laporan keuangan tiga tahun terakhir $(2015,2016,2017)$.

Meningkatnya berbagai kasus skandal akuntansi di dunia menyebabkan berbagai pihak berspekulasi bahwa manajemen telah melakukan kecurangan pada laporan keuangan (Skousen et al., 2009). Oleh karena itu, untuk mengatasi kelemahan pada prosedur pendeteksian kecurangan, Institut Akuntan Publik Indonesia pada tahun 2001 menerbitkan Pernyataan Standar Audit (PSA) No. 70 tentang Pertimbangan Atas Kecurangan dalam Audit Laporan Keuangan. Tujuan yang dinyatakan dalam PSA No.70 yaitu untuk mengarahkan auditor dalam meningkatkan pendeteksian kecurangan melalui penilaian faktor - faktor risiko kecurangan yang menjadi elemen penting dalam ruang lingkup perikatan audit (IAI, 2001).
Penilaian faktor risiko kecurangan dalam PSA No.70 banyak yang mengadopsi beberapa standar pengauditan mengenai pendeteksian kecurangan (yakni SAS No.82, ISA 240, dan SAS No.99), dan merujuk pada teori faktor risiko kecurangan yang dikembangkan oleh Cressey (1953) yaitu tekanan (pressure), kesempatan (opportunity), dan rasionalisasi (rationalization), yang sering disebut dengan Fraud Triangle. Menurut Wolfe dan Hermanson (2004), fraud triangle dapat ditingkatkan guna mendeteksi dan mencegah kecurangan dengan mempertimbangkan elemen keempat, yaitu kemampuan (capability) dan dikenal sebagai Fraud Diamond.

Penelitian ini bertujuan untuk menganalisis dan menemukan bukti empiris atas: (1) pengaruh faktor risiko Pressure dengan kategori Financial Stability, External Pressure, Personal Financial Need, dan Financial Target terhadap Financial Statement Fraud (2) pengaruh faktor risiko Opportunity dengan kategori Nature of Industry dan Ineffective Monitoring terhadap Financial Statement Fraud (3) pengaruh faktor risiko Rationalization dengan kategori roksi Opinion Auditor, Change in Auditor dan Total Accrual terhadap Financial Statement Fraud (4) pengaruh faktor risiko Capability dengan kategori Change in Director terhadap Financial Statement Fraud

Penelitian ini diharapkan dapat memberikan urgensi terhadap pihak-pihak terkait yang berhubungan dengan rumpun ilmu Ekonomi Akuntansi adalah (1) bagi pihak emiten di bidang perbankan, memberikan kontribusi terkait indikasi adanya kecurangan dalam laporan keuangan, sehingga dapat ditindaklanjuti sebelum merugikan pihak eksternal yang menggunakan laporan keuangan sebagai dasar dalam pengambilan keputusan. (2) bagi regulator/ pemerintah, dapat memberikan kontribusi kebijakan lebih lanjut dengan membuat peraturan-peraturan yang mendukung terciptanya perekonomian yang memadai.

\section{Telaah Teori}

\section{Financial Statement Fraud (Kecurangan Laporan Keuangan)}

Statement of Auditing Standards No.99 mendefinisikan financial statement fraud sebagai tindakan atau perbuatan yang disengaja untuk menghasilkan salah saji material dalam laporan keuangan yang merupakan subjek audit. Kecurangan laporan keuangan dapat terjadi karena disebabkan 
adanya ketidakjelasan dalam pemisahan tugas dan tanggung jawab pada masing-masing pihak di perusahaan, sehingga menimbulkan spekulasi untuk melakukan manipulasi, kolusi dan korupsi untuk kepentingan pribadi.

Financial Statement Fraud dapat dilakukan dengan berbagai cara, salah satunya melalui earning management. Menurut Rezaee (2002), financial statement fraud berkaitan erat dengan tindakan manipulasi laba yang dilakukan manajemen agar perusahaan terlihat baik dibandingkan perusahaan lain yang sejenis. Tindakan manipulasi laba yang digunakan oleh manajemen perusahaan sebagai gimmick akuntansi bertujuan untuk memberikan hasil yang sesuai dengan harapan agar menaikkan harga saham dan kompensasi eksekutif menjadi lebih tinggi.

\section{Fraud Triangle}

Fraud Triangle Theory merupakan konsep segitiga kecurangan yang dikemukakan oleh Cressey (1953) yang menyimpulkan bahwa faktor pemicu terjadinya kecurangan yakni tekanan, kesempatan, dan rasionalisasi. Individu yang memiliki integritas personal yang baik dan tidak berada pada tekanan situasional yang berat, serta terbatasnya kesempatan untuk melakukan kecurangan, maka individu tersebut akan cenderung bersikap jujur. Sehingga, dapat disimpulkan bahwa individu yang terlibat dalam tindak kecurangan didorong oleh interaksi antara kekuatan-kekuatan dalam kepribadian individu dengan lingkungan eksternal. Dalam hal ini risiko terjadinya kecurangan cenderung akan semakin besar apabila seseorang berada dalam tekanan situasional, ada kesempatan dan yang bersangkutan memiliki integritas yang rendah (Hall, 2001). Adapun faktor penyebab terjadinya kecurangan (fraud) yaitu :

a. Tekanan (Pressure).

Menurut Cressey (dalam Hillison, et al. 1999), tekanan merupakan insentif yang mendorong orang melakukan kecurangan karena tuntutan gaya hidup, ketidakberdayaan dalam keuangan, perilaku gambling, mencoba-coba untuk mengalahkan sistem dan ketidakpuasan kerja. Menurut SAS No. 99 berikut empat tekanan yang dapat menyebabkan seseorang terlibat dalam kecurangan yaitu stabilitas keuangan (financial stability) perusahaan, tekanan eksternal (external pressure) bagi manajemen, situasi keuangan pribadi (personal financial need) manajemen, dan target keuangan (financial target) yang ditetapkan oleh direksi atau manajemen. b. Kesempatan (Opportunity).

Cressey (dalam Skousen,et al. 2009) berpendapat bahwa tanpa adanya kesempatan, seseorang tidak dapat melakukan penipuan. Kesempatan ini umumnya timbul dalam sistem pengendalian yang lemah. Selain itu, jika sebuah perusahaan memiliki sistem pengendalian yang lemah maka kesempatan untuk melakukan fraud akan timbul. Namun demikian sistem pengendalaian yang bagus pun tetap memungkinkan terjadinya fraud yang umumnya dilakukan oleh mereka yang merupakan orang kepercayaan atau mereka yang memiliki wewenang. SAS No. 99 mengutip empat peluang berikut yang memungkinkan seseorang untuk terlibat dalam kecurangan yaitu sifat industri (nature of industry), pengawasan manajemen yang tidak efektif (ineffective monitoring), dan struktur organisasi yang kompleks atau tidak stabil (organizational structure),

c. Rasionalisasi (Rationalization).

Rasionalisasi sebagai pemikiran yang menjustifikasi tindakannya sebagai suatu perilaku yang wajar, yang secara moral dapat diterima dalam suatu masyarakat yang normal. Hal ini dilakukan untuk menenangkan perasaan yang bersangkutan sehingga jika dilakukan tidak menimbulkan ketakutan dalam dirinya. Rasionalisasi umumnya berkaitan dengan integritas, kode etik dan nilai-nilai yang dianut oleh seseorang (Cressey dalam Hillison, et al. 1999).

Cressey (dalam Skousen,et al. 2009) berpendapat bahwa rasionalisasi merupakan komponen terpenting sebelum terjadi kecurangan, sebab rasionalisasi adalah bagian dari motivasi (seperti tekanan) untuk kejahatan. Rasionalisasi merupakan bagian dari fraud triangle yang sulit diukur.

\section{Fraud Diamond}

Fraud Diamond Theory merupakan gagasan dan konsep mengenai fenomena kecurangan yang dikemukakan oleh Wolfe dan Hermanson pada bulan Desember 2004. Fraud diamond dipandang sebagai pernyempurnaan yang diperluas dari fraud triangle theory. Wolfe dan Hermanson (2004) mengatakan banyak kecurangan tidak akan terjadi tanpa adanya orang yang tepat yang memiliki kemampuan untuk melakukan kecurangan. Posisi seseorang atau fungsi dalam organisasi dapat memberikan kemampuan untuk membuat atau memanfaatkan kesempatan agar kecurangan tidak tersedia untuk orang lain. Maka, dapat dikatakan bahwa kemampuan (capability) 


\section{Jurnal Akuntansi dan Pajak, 20(02), 2019, 112}

menjadi faktor risiko yang mendorong seseorang untuk melakukan fraud.

Wolfe dan Hermanson (2004) menjelaskan sifat-sifat terkait dengan faktor capability dalam pribadi perilaku kecurangan, antara lain posisi (position), kecerdasan (intelligence), tingkat kepercayaan diri (convidence), kemampuan memaksa (coercion skills), kebohongan yang efektif (deceit/ effective lying), dan kekebalan terhadap stres (immunity to stress)

\section{Kerangka Teoritis dan Hipotesis}

Dalam penelitian ini menggunakan sepuluh variabel independen dan, variabel dependen penelitian ini yaitu financial statement fraud

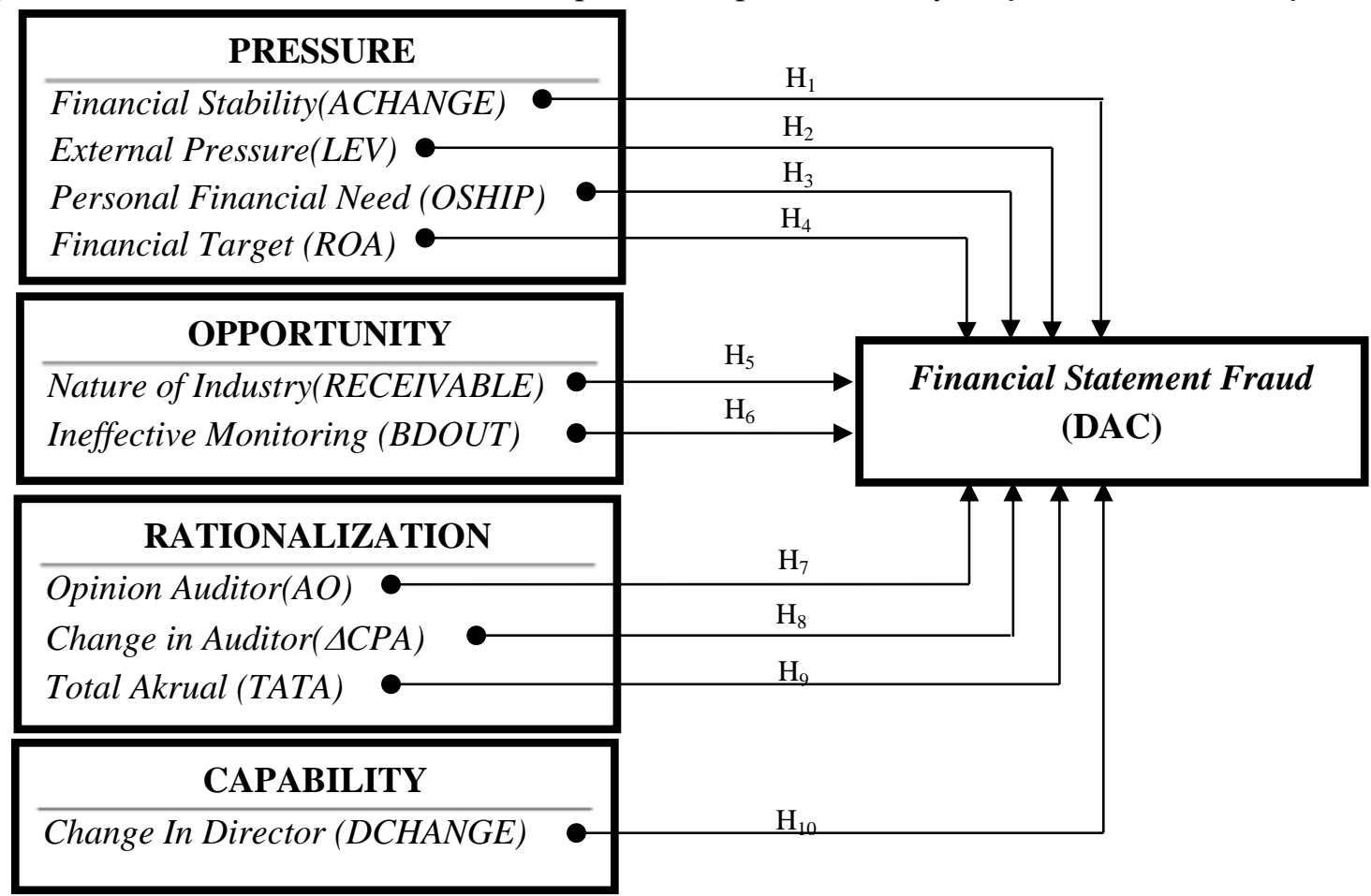

Hubungan antar variabel independen dan variabel dependen dalam penelitian ini dapat dijelaskan sebagai berikut :

\section{a) Pengaruh Pressure dengan kategori \\ Financial Stability terhadap Financial \\ Statement Fraud}

SAS No. 99 (dalam Skousen,et al. 2009) menjelaskan bahwa manajer mengalami tekanan untuk melakukan kecurangan laporan keuangan ketika stabilitas keuangan atau profitabilitas perusahaan terancam oleh kondisi ekonomi, industri dan situasi entitas yang beroperasi. Loebbecke, et al. (dalam Skousen,et al. 2009) menunjukkan bahwa perusahaan yang mengalami pertumbuhan berada di bawah rata-rata industri, maka manajemen akan memanipulasi laporan keuangan untuk meningkatkan performa perusahaan. Semakin tinggi total aset yang dimiliki perusahaan menunjukan kekayaan yang dimiliki semakin besar. Hal ini dapat dijadikan dasar bagi investor untuk mengalokasikan dana yang ingin diinvestasikannya, maka manajemen akan menyajikan laporan keuangan perusahaan sebaik mungkin agar dapat menarik para investor. Semakin tinggi persentase perubahan total aset maka praktek kecurangan dalam laporan keuangan juga semakin tinggi. Berdasarkan uraian diatas, maka hipotesis yang diajukan yaitu :

$\mathrm{H}_{1}$ : Financial Stability berpengaruh terhadap Financial Statement Fraud

b) Pengaruh Pressure dengan kategori External Pressure terhadap Financial Statement Fraud

External Pressure merupakan tekanan berlebihan bagi manajemen untuk memenuhi persyaratan atau harapan dari pihak ketiga. Skousen, et al. (2009) berpendapat bahwa salah satu tekanan yang seringkali dialami manajemen perusahaan adalah kebutuhan tambahan utang atau sumber pembiayaan eksternal agar tetap kompetitif, termasuk pembiayaan riset dan pengeluaran pembangunan atau modal. Risiko kredit yang tinggi menimbulkan kekhawatiran bahwa perusahaan tersebut tidak mampu untuk mengembalikan pinjaman yang diberikan. Oleh karena itu, perusahaan harus menyelamatkan diri dari kondisi tersebut agar dianggap mampu untuk mengembalikan hutang-hutangnya, dengan cara melakukan kecurangan. Maka secara relevan dikatakan bahwa semakin besar external pressure yang diproksikan dengan rasio leverage maka kemungkinan terjadinya financial statement fraud 
atau kecurangan laporan keuangan akan tinggi. Berdasarkan uraian diatas, maka hipotesis yang diajukan yaitu :

$\mathrm{H}_{2}$ : External Pressure berpengaruh terhadap Financial Statement Fraud

c) Pengaruh Pressure dengan kategori Personal Financial Need terhadap Financial Statement Fraud

Menurut SAS No. 99 (dalam Skousen,et al. 2009), personal financial need merupakan suatu kondisi keuangan perusahaan yang dipengaruhi oleh kondisi keuangan pribadi para eksekutif perusahaan. Beasley (1996), COSO (1999), dan Dun (2004) menunjukkan bahwa ketika eksekutif perusahaan (dewan komisaris dan dewan direksi) memiliki kepentingan keuangan yang signifikan dalam perusahaan, maka situasi keuangan pribadi mereka akan mengancam kinerja keuangan perusahaan. Hal ini disebabkan karena manajemen memiliki peran ganda sebagai pelaksana sekaligus sebagai pemilik sehingga dapat dengan mudah melakukan kecurangan dengan membuat hasil performa tertentu untuk memperoleh dividen dan return saham yang tinggi. Berdasarkan uraian diatas, maka hipotesis yang diajukan yaitu :

$\mathrm{H}_{3}$ : Personal Financial Need berpengaruh terhadap Financial Statement Fraud

d) Pengaruh Pressure dengan kategori Financial Target terhadap Financial Statement Fraud

Financial target merupakan risiko karena adanya tekanan berlebihan pada manajemen untuk mencapai target keuangan yang ditetapkan oleh direksi atau manajemen (Yesiariani, 2016), adanya dorongan yang ingin diraih tetapi dibatasi oleh ketidakmampuan akan mengakibatkan seseorang melakukan tindakan kecurangan (Albrecht, dalam Puspitadewi, 2017). Dalam menjalankan kinerjanya, manajer senantiasa dituntut untuk bisa mencapai target keuangan yang telah direncanakan agar dapat menarik investor karena ROA yang tinggi dianggap mampu menghasilkan laba yang tinggi (Skousen et. al., 2008). Berdasarkan uraian diatas, maka hipotesis yang diajukan yaitu :

$\mathrm{H}_{4}$ : Financial Target berpengaruh terhadap Financial Statement Fraud

e) Pengaruh faktor risiko Opportunity dengan kategori Nature of Industry terhadap Financial Statement Fraud

Nature of Industry merupakan kondisi ideal suatu perusahaan atau organisasi dalam industri.
Penilaian estimasi pada persediaan yang usang dan piutang tak tertagih memungkinkan manajemen untuk melakukan manipulasi (Summer dan Sweeney, dalam Skousen, 2009). Salah satu bentuk dari nature of industry yaitu kondisi piutang perusahaan, perusahaan yang baik akan menekan dan memperkecil jumlah piutang perusahaan serta memperbanyak penerimaan aliran kas perusahaan (Skousen, 2009). Tingginya piutang dalam penjualan menunjukkan bahwa account piutang merupakan aset yang memiliki resiko manipulasi lebih tinggi, sehingga rawan terjadi kecurangan dalam laporan keuangan melalui account piutang (Dalnial, et. al. ,2014). Berdasarkan uraian diatas, maka hipotesis yang diajukan yaitu :

$\mathrm{H}_{5}$ : Nature of Industry berpengaruh terhadap Financial Statement Fraud

f) Pengaruh faktor risiko Opportunity dengan kategori Ineffective Monitoring terhadap Financial Statement Fraud

Ineffective monitoring merupakan keadaan yang menggambarkan lemah atau tidak adanya pengawasan efektif dalam memantau kinerja perusahaan. Pengawasan yang tidak efektif ini sebagai akibat adanya dominasi manajemen oleh satu orang atau kelompok kecil tanpa adanya kontrol kompensasi serta tidak efektifnya pengawasan terhadap proses pelaporan keuangan dan pengendalian internal (SAS No.99). Menurut Skousen et al. (2009), perusahaan yang melakukan kecurangan cenderung memiliki dewan komisaris yang sedikit. Oleh karena itu, semakin kecil rasio dewan komisaris maka akan semakin tidak efektif pengawasan dalam memantau kinerja perusahaan, sehingga semakin tinggi kecenderungan terjadi kecurangan dalam laporan keuangan. Berdasarkan uraian tersebut, diajukan hipotesis penelitian sebagai berikut:

\section{$\mathrm{H}_{6}$ : Ineffective Monitoring berpengaruh terhadap Financial Statement Fraud \\ g) Pengaruh faktor risiko Rationalization dengan kategori Opinion Auditor terhadap Financial Statement Fraud}

Rasionalisasi merupakan faktor yang sulit diukur untuk mendeteksi kecurangan seperti manajemen laba. Hal ini karena rasionalisasi merupakan suatu pembenaran atas apa yang dilakukan pelaku kecurangan terhadap apa yang telah dilakukannya (Skousen et al. 2009). Namun, auditor lebih mentolerir usaha klien untuk mengelola laba dari waktu ke waktu (Varmer, dalam Fimanaya

Jurnal Akuntansi dan Pajak, ISSN 1412-629X I E-ISSN 2579-3055 


\section{Jurnal Akuntansi dan Pajak, 20(02), 2019, 114}

dan Syafruddin, 2014) , sehingga auditor dapat memberikan beberapa opininya atas perusahaan yang diauditnya sesuai dengan keadaan yang terjadi pada perusahaan tersebut. Salah satu opini auditor yang diberikan yaitu Wajar Tanpa Pengecualian (WTP) dengan bahasa penjelas. Opini tersebut merupakan bentuk tolerir dari auditor atas manajemen laba (Fimanaya dan Syafruddin 2014). Opini tersebut memungkinkan manajemen untuk bersikap rasionalisasi atau mengklaim bahwa apa yang dilakukannya bukanlah sesuatu yang salah. Berdasarkan uraian tersebut, diajukan hipotesis penelitian sebagai berikut:

$\mathrm{H}_{7}$ : Opinion Auditor berpengaruh terhadap Financial Statement Fraud

h) Pengaruh faktor risiko Rationalization dengan kategori Change in Auditor terhadap Financial Statement Fraud

Dalam SAS No. 99 menyatakan bahwa hubungan manajemen dengan auditor merupakan rasionalisasi manajemen, sehingga adanya pergantian auditor dalam perusahaan menjadi indikasi terjadinya kecurangan. Menurut Skousen et al. (2009), kegagalan audit dalam mendeteksi kecurangan laporan keuangan meningkat sesaat seteleh terjadinya pergantian auditor. Berdasarkan uraian tersebut, diajukan hipotesis penelitian sebagai berikut:

\section{$\mathrm{H}_{8}$ : Change in Auditor berpengaruh terhadap Financial Statement Fraud}

i) Pengaruh faktor risiko Rationalization dengan kategori Total Akrual terhadap Financial Statement Fraud

Rasionalisasi merupakan prinsip akrual berhubungan dengan pengambilan keputusan manajemen dan memberikan wawasan terhadap rasionalisasi dalam pelaporan keuangan (Vermeer, 2003). Menurut Skousen, et. al (2009), rasionalisasi memiliki penilaian subjektif bagi perusahaan, penilaian serta pengambilan keputusan yang subjektif tersebut akan tercermin pada nilai akrual perusahaan. Maka dalam penelitian ini akan menggunakan proksi Total Akrual to Total Asset (TATA) sebagai proksi pengaruh rasionalisasi terhadap kecurangan laporan keuangan karena konsep akrual memungkinkan manajemen dapat memanipulasi pendapatan. Berdasarkan uraian tersebut, diajukan hipotesis penelitian sebagai berikut:

\section{H9: Total Akrual berpengaruh terhadap Financial Statement Fraud}

j) Pengaruh faktor risiko Capability dengan kategori Change In Director terhadap Financial Statement Fraud

Wolfe dan Hermanson (2004) menyatakan bahawa posisi seseorang atau fungsi dalam organisasi dapat memberikan kemampuan untuk memanfaatkan kesempatan melakukan kecurangan. Berdasarkan hal tersebut, posisi CEO, direksi, dan kepala divisi dapat menjadi faktor penentu terjadi kecurangan. Perubahan direksi umumnya berkaitan dengan muatan politis dan kepentingan pihak tertentu karena ada target yang terlalu besar yang diberikan oleh perusahaan ataupun ada perjanjian bonus kompensasi yang besar sehingga memicu conflict of interest karena perubahan direksi dianggap upaya perusahaan untuk menyingkirkan direksi yang dianggap mengetahui adanya kecurangan yang dilakukan perusahaan. Semakin sering terjadinya pergantian direksi maka semakin tinggi pula indikasi terjadinya kecurangan laporan keuangan. Berdasarkan uraian tersebut, diajukan hipotesis penelitian sebagai berikut:

\section{$\mathrm{H}_{10}$ : Change In Director berpengaruh terhadap Financial Statement Fraud}

\section{Metode Penelitian}

Variabel dependen (Y) dalam penelitian ini adalah Financial Statement Fraud yang diproksikan dengan earning management, yaitu nilai discretionary accrual dari Modified Jones Model. Pengukuran akrual diskresioner yang versi crosssectional dari model Modified Jones yang relatif terbaik dalam menganalisis akrual normal perusahaan terhadap perubahan dalam penjualan dan nilai aktiva tetap perusahaan.

$$
\mathrm{DAC}_{\mathrm{it}}=\mathrm{TACC}_{\mathrm{it}} / \mathrm{TA}_{\mathrm{it}-1}-\mathrm{NDAC}_{\mathrm{it}}
$$

Dimana :

$\mathrm{TACC}_{\mathrm{it}}=$ total akrual perusahaan i untuk tahun $\mathrm{t}$.

$\mathrm{TA}_{\mathrm{it}-1}=$ total aset perusahaan $\mathrm{i}$ untuk tahun $\mathrm{t}-1$.

$\mathrm{DAC}_{\mathrm{it}}=$ discretionary accrual perusahaan $\mathrm{i}$ untuk tahun $\mathrm{t}$.

$\mathrm{NDAC}_{\mathrm{it}}=$ non-discretionary accrual perusahaan $\mathrm{i}$ untuk tahun $\mathrm{t}$.

Variabel independen (X) dalam penelitian ini adalah sebagai berikut :

\section{a. Financial Stability (Pressure)}

Financial stability $\left(\mathrm{X}_{1}\right)$ merupakan keadaan yang menggambarkan kondisi keuangan perusahaan dalam kondisi stabil. Apabila kondisi keuangan perusahaan dalam kondisi tidak stabil, maka risiko terjadi financial statement fraud menurun. 


\begin{tabular}{|c|} 
Jurnal Akuntansi dan \\
ACHANGE $=\frac{(\text { Total Aset }}{\mathrm{t}}-\frac{\text { Total Aset }}{\mathrm{t}-1)}$ \\
Total Aset $\mathrm{t}_{\mathrm{t}-1}$
\end{tabular}

\section{b. External Pressure (Pressure)}

External pressure $\left(\mathrm{X}_{2}\right)$ merupakan tekanan yang berlebihan bagi manajemen untuk memenuhi persyaratan atau harapan dari pihak ketiga. External pressure diproksikan dengan rasio leverage (LEV) yang dihitung dengan rumus Debt to Assets Ratio.

LEV $=\frac{\text { Total Kewajiban }}{\text { Total Aset }}$

\section{c. Personal Financial Need (Pressure)}

Personal financial need $\left(\mathrm{X}_{3}\right)$ merupakan suatu keadaan keuangan perusahaan yang dipengaruhi oleh kondisi keuangan para eksekutif perusahaan. Personal financial need diproksikan dengan ownership in the firm hold by insider (OSHIP) yang merupakan rasio kepemilikan saham oleh orang dalam (Skousen, et. al, 2009).

\section{OSHIP $=\underline{\text { Total saham dimiliki eksekutif }}$ \\ Total saham yang beredar}

\section{d. Financial Target (Pressure)}

Financial target $\left(\mathrm{X}_{4}\right)$ merupakan risiko adanya tekanan berlebihan pada manajemen untuk mencapai target keuangan yang dipatok oleh direksi atau manajemen, termasuk tujuan penerimaan insentif dari penjualan maupun keuntungan. Financial target diproksikan dengan Return on Assets (ROA) merupakan bagian dari rasio profitabilitas dalam analisis laporan keuangan atau pengukuran kinerja perusahaan (Skousen, et. al, 2009).

$$
\mathrm{ROA}=\frac{\text { Laba setelah pajak }}{\text { Total Aset }}
$$

\section{e. Nature of Industry (Opportunity)}

Nature of industry $\left(\mathrm{X}_{5}\right)$ merupakan keadaan ideal suatu perusahaan. Nature of industry diproksikan RECEIVABLE yang berkaitan dengan piutang yaitu rasio perubahan dalam piutang usaha (Skousen, et. al, 2009).

$$
\text { RECEIVABLE }=\underline{\text { Piutang }}_{\text {Penjualan }_{t}}^{\text {Penjualan }_{t-1}}-\underline{\text { Piutang }_{t-1}}
$$

\section{f. Ineffective Monitoring (Opportunity)}

Ineffective monitoring $\left(\mathrm{X}_{6}\right)$ merupakan keadaan yang menggambarkan lemah atau tidak adanya pengawasan efektif dalam memantau kinerja perusahaan. Ineffective monitoring diproksikan BDOUT dengan rasio komisaris yang berasal dari luar perusahaan terhadap keseluruhan anggota dewan komisaris.

\section{BDOUT $=\underline{\text { Total komisaris independen }}$ \\ Total dewan komisaris}

\section{g. Opinion Auditor (Rationalization)}

Rasionalisasi $\left(\mathrm{X}_{7}\right)$ merupakan suatu pembenaran atas apa yang dilakukan pelaku kecurangan terhadap apa yang telah dilakukannya (Skousen et al. 2009). Rationalization diproksikan dengan auditor opinion (AO) yang diukur yang dengan variabel dummy. Apabila perusahaan yang mendapat opini wajar tanpa pengecualian dengan bahasa penjelas selama periode 2014-2018 maka diberi kode 1, dan apabila perusahaan yang mendapat selain opini tersebut maka diberi kode 0 .

\section{h. Change in Auditor (Rationalization)}

Change in Auditor $\left(\mathrm{X}_{8}\right)$ merupakan rasionalisasi manajemen, sehingga adanya pergantian auditor dalam perusahaan menjadi indikasi terjadinya kecurangan. Rationalization diproksikan dengan change in auditor ( $\triangle C P A$ ) yang diukur yang dengan variabel dummy. Apabila perusahaan melakukan pergantian auditor diberi angka 1 dan apabila perusahaan tidak mengganti auditornya selama masa penelitian maka diberi kode 0 .

\section{i. Total Akrual (Rationalization)}

Total Akrual $\left(\mathrm{X}_{9}\right)$, merupakan rasionalisasi yang memiliki penilaian subjektif bagi perusahaan, penilaian serta pengambilan keputusan yang subjektif tersebut akan tercermin pada nilai akrual perusahaan (Skousen, et. al, 2009). Oleh karena itu, rationalization akan diproksikan dengan rasio total akrual (TATA).

TATA $=\underline{(\text { Net Income }- \text { Cash Flow Operational })}$ Total Assets

\section{j. Change in Director (Capability)}

Change in Director $\left(\mathrm{X}_{10}\right)$ merupakan kapasitas dan seberapabesar daya dari seseorang untuk melakukan fraud di lingkungan perusahaan. Capability diproksikan dengan pergantian direksi perusahaan (DCHANGE) yang diukur dengan variabel dummy. Apabila terdapat perubahan direksi perusahaan selama periode 2014-2018 maka diberi kode 1 , sebaliknya apabila tidak terdapat perubahan direksi perusahaan selama periode 2014-2018 maka diberi kode 0 .

\section{Obyek Penelitian}

Populasi dalam penelitian ini meliputi semua perusahaan publik yang terdaftar di Bursa Efek 


\section{Jurnal Akuntansi dan Pajak, 20(02), 2019, 116}

Indonesia (BEI) periode tahun 2014-2018. Perusahan publik yang digunakan sebagai obyek penelitian memiliki aktivitas operasional di bidang perbankan. Metode pemilihan sampel menggunakan metode purposive sampling yaitu pemilihan sampel berdasarkan tujuan penelitian dengan pertimbangan khusus. Adapun kriteria-kriteria dalam pengambilan sampel yaitu:

1) Perusahaan perbankan yang sudah go public atau yang terdaftar di Bursa Efek Indonesia berturut-turut selama periode tahun 2014-2018.

2) Perusahaan mempublikasikan laporan keuangannya pada website BEI selama periode berturut-turut 2014-2018 yang dinyatakan dalam rupiah $(\mathrm{Rp})$.

3) Perusahaan yang mengalami laba selama periode pengamatan.

4) Perusahaan yang mengungkapkan data-data berkaitan dengan variabel penelitian dan tersedia secara lengkap.

5) Perusahaan yang tidak delisting selama periode pengamatan.

6) Perusahaan yang memiliki laporan auditan setiap tahunnya.

\section{Metode Analisis Data}

Penelitian ini menggunakan tehnik analisis statistik deskriptif untuk menggambarkan variabelvariabel dalam penelitian. Penelitian ini sebelumnya didahului dengan pengujian asumsi klasik sebelum menggunakan analisis regresi berganda, agar pengambilan keputusan mendekati keadaan yang sebenarnya, serta pengujian hipotesis untuk menguji apakah hipotesis diterima atau ditolak.

Uji asumsi klasik yang digunakan dalam penelitian ini, antara lain meliputi :

a. Uji normalitas bertujuan untuk menguji apakah dalam sebuah model regresi baik variabel independen maupun variabel dependen memiliki distribusi yang normal melalui analisis Kolmogorov-Smirnov Normality Test dan melihat normal probability plot.

b. Uji heteroskedastisitas bertujuan untuk mengetahui apakah dalam model regresi tidak terjadi kesamaan variace dari residual satu pengamatan ke pengamatan yang lain, dilakukan dengan melihat scatter plot dan menggunakan uji glejser.

c. Uji multikolinearitas digunakan untuk mengetahui adanya korelasi antara variabel independen yang satu dengan yang lainya

dengan mendeteksi nilai VIF (Variance Inflation Factor) dan nilai tolerance.

d. Uji autokorelasi digunakan untuk mengetahui apakah dalam penggunaan model regresi ada korelasi antara kesalahan pada periode t dengan kesalahan pada periode t-1 (sebelumnya), dengan menggunakan model Durbin Watson $(d \mathrm{~W})$.

\section{Teknik Analisis Data}

Model penelitian ini menggunakan analisis regresi berganda yang bertujuan untuk memprediksi perubahan hubungan beberapa variabel independen dan variabel dependen dengan persamaan sebagai berikut:

$$
\begin{aligned}
\mathrm{DAC}_{\mathrm{it}}= & \beta_{0}+\beta_{1} \text { ACHANGE }+\beta_{2} \mathrm{LEV}+\beta_{3} \mathrm{OSHIP}+ \\
& \beta_{4} \text { ROA }+\beta_{5} \text { RECEIVABLE }+\beta_{6} \text { BDOUT }+ \\
& \beta_{7} \text { AO }+\beta_{8} \Delta \text { CPA }+\beta_{9} \text { TATA }+ \\
& \beta_{10} \text { DCHANGE }+\varepsilon
\end{aligned}
$$

Keterangan :

$\beta_{0}$

$\beta_{1-10}$

$\mathrm{DAC}_{\mathrm{it}}$

ACHANGE : Rasio perubahan total aset

LEV : Rasio total kewajiban per total aset

OSHIP : Rasio kepemilikan saham oleh orang dalam

ROA : Rasio profitabilitas

RECEIVABLE: Rasio perubahan dalam piutang usaha

BDOUT : Rasio komisaris dari luar perusahaan per total dewan komisaris

AO : Opini auditor

$\triangle \mathrm{CPA} \quad$ : Pergantian auditor independen

TATA : Rasio total akrual per total aset

DCHANGE : Pergantian direksi

$\varepsilon$

Tahapan dalam pengujian hubungan variabel independen dan variabel dependen, meliputi :

a. Uji $\mathrm{F}$ bertujuan untuk menguji apakah seluruh variabel independen secara simultan berpengaruh signifikan terhadap variabel dependen. Pengambilan keputusan dilakukan berdasarkan pada nilai signifikan. Apabila nilai signifikan lebih kecil dari taraf signifikansi 0,05 maka Ha diterima atau Ho ditolak, artinya seluruh variabel independen secara simultan 


\section{Jurnal Akuntansi dan Pajak, 20(02), 2019, 117}

berpengaruh signifikan terhadap variabel dependen.

b. Uji koefisien determinasi dilakukan dengan tujuan untuk mengetahui seberapa besar kemamypuan variabel independen dapat menjelaskan variabilitas variabel dependen melalui adjusted $\mathrm{R}^{2}$ yang memiliki nilai antara 0 sampai dengan 1 .

c. Uji t bertujuan untuk menguji hubungan yang signifikan antara variabel independen terhadap variabel dependen secara parsial. Pengambilan keputusan dilakukan berdasarkan dengan melihat nilai signifikansinya.

\section{Hasil Pembahasan}

\subsection{Hasil Penelitian}

Pada penelitian ini jumlah sampel yang sesuai kriteria adalah sebanyak 29 perusahaan dengan periode pengamatan adalah 5 tahun dengan jumlah keseluruhan sampel dalam penelitian ini adalah 143 laporan tahunan. Namun, dalam pengujian yang dilakukan terdapat permasalahan data dalam model regresi sehingga jumlah sampel yang digunakan adalah sebanyak 128 laporan tahunan setelah dilakukan transformasi data dan pembuangan outlier.

Statistik deskriptif dalam penelitian ini setelah dilakukan pembuangan data-data yang outlier yaitu sebanyak 128 perusahaan ditampilkan pada tabel 2 (lihat lampiran). Variabel tekanan (pressure) yang diproksikan dengan financial stability (ACHANGE) nilai terendah dimiliki Bank CIMB Niaga tahun buku 2018 dan nilai tertinggi adalah Bank Woori Saudara Indonesia tahun buku 2014. Variabel tekanan (pressure) yang diproksikan dengan external pressure (LEV) nilai terendah dimiliki Bank Ina Perdana tahun buku 2017 dan nilai tertinggi dimiliki oleh Bank Bukopin tahun buku 2017.Variabel tekanan (pressure) yang diproksikan dengan personal financial feed (OSHIP) menghasilkan nilai rata-rata adalah sebesar 0,0056 artinya sebesar $0,56 \%$ saham dimiliki oleh orang dalam. Variabel tekanan (pressure) yang diproksikan dengan financial target (ROA) nilai terendah adalah Bank Bukopin tahun buku 2017 dan nilai tertinggi adalah BCA tahun buku 2018.

Variabel kesempatan (opportunity) yang diproksikan nature of industry (RECEIVABLE) memiliki nilai terendah oleh Bank Victoria International tahun buku 2017 dan nilai tertinggi milik Bank Woori Saudara Indonesia tahun buku 2014. Variabel kesempatan (opportunity) yang diproksikan ineffective monitoring (BDOUT) menghasilkan nilai rata-rata adalah sebesar 0,5774 artinya sebesar $57,74 \%$ terdapat dewan komisaris independen dalam perusahaan. Nilai terendah BDOUT dimiliki oleh Bank Mayapada tahun buku 2015 dan 2016, BPD Jatim tahun buku 2015,2016 dan 2017, Bank Mega tahun buku 2017 sedangkan nilai tertinggi dimiliki oleh Bank National NOBU tahun buku 2017.

Variabel rasionalisasi (rationalization) yang diproksikan dengan auditor opinion (AO) menghasilkan nilai rata-rata sebesar 0,9844 artinya sebesar 98,44\% sampel memperoleh opini wajar tanpa pengecualian dengan bahasa penjelas. Variabel rasionalisasi (rationalization) yang diproksikan dengan change in auditor (CPA) menghasilkan nilai rata-rata 0,1328 artinya sebesar $13,28 \%$ sampel melakukan pergantian auditor. Variabel rasionalisasi (rationalization) yang diproksikan dengan total accrual (TATA) nilai terendah adalah Bank National NOBU tahun buku 2014 dan nilai tertinggi dimiliki oleh Bank Mega tahun buku 2018.

Variabel kemampuan (capability) yang diproksikan dengan change in director (DCHANGE) menghasilkan nilai rata-rata sebesar 0,6484 artinya sebesar $64,84 \%$ sampel sampel melakukan pergantian direksi.

\section{Tabel 3}

Hasil Uji Kolmogorov-Smirnov

(Sebelum pembuangan data outlier)

\begin{tabular}{ll|r}
\hline & \multicolumn{1}{|c}{$\begin{array}{c}\text { Unstandardized } \\
\text { Residual }\end{array}$} \\
\hline $\mathrm{N}$ & & 135 \\
Normal & Mean & 0.0000000 \\
Parameters $^{\mathrm{a}}$ & Std. Deviation & 0.01960698 \\
Most Extreme & Absolute & 0.133 \\
Differences & Positive & 0.085 \\
& Negative & -0.133 \\
Kolmogorov-Smirnov Z & $\mathbf{1 . 5 4 9}$ \\
Asymp. Sig. (2-tailed) & $\mathbf{0 . 0 1 6}$ \\
\hline
\end{tabular}

a. Test distribution is Normal.

Sumber : Data yang telah diolah (2019)

Berdasarkan tabel 3 asumsi uji normalitas belum terpenuhi, maka dilakukan pembuangan terhadap data-data yang outlier agar distribusi data dalam penelitian ini normal atau memenuhi asumsi normalitas. Hal ini dibuktikan dengan memperoleh nilai Kolmogorov-Smirnov sebesar 1,246 dan nilai 


\section{Jurnal Akuntansi dan Pajak, 20(02), 2019, 118}

Asymp. Sig. (2-tailed) sebesar 0,090. Selain itu, hasil normal probability plot pada gambar 1 (lihat lampiran) yang menunjukkan adanya titik-titik penyebaran di sekitar garis diagonal dan penyebarannya mengikuti arah garis diagonal. Maka, model regresi ini layak dipakai untuk memprediksikan Financial Statement Fraud yang diproksikan dengan earning management melalui nilai discretionary accrual.

Tabel 4

Hasil Uji Kolmogorov-Smirnov

(Setelah pembuangan data outlier)

\begin{tabular}{ll|r}
\hline & & \multicolumn{1}{|c}{ Unstandardized } \\
Residual
\end{tabular}

a. Test distribution is Normal.

Sumber : Data yang telah diolah (2019)

Pada output hasil uji Glejser terdapat masalah heterokedastisitas bahwa nilai signifikansi pada variabel ACHANGE dan LEV lebih kecil dari 0,05 sehingga dilakukan transformasi data agar uji Glejser memenuhi asumsi heterokedastisitas.

Tabel 5

Hasil Uji Glejser

(Sebelum transformasi data)

\begin{tabular}{|c|c|c|c|c|c|}
\hline \multirow{2}{*}{ Model } & \multicolumn{2}{|c|}{$\begin{array}{l}\text { Unstandardized } \\
\text { Coefficients }\end{array}$} & \multirow{2}{*}{ 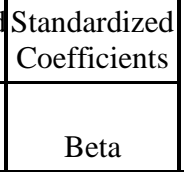 } & & \multirow{2}{*}{ Sig. } \\
\hline & B & $\begin{array}{l}\text { Std. } \\
\text { Error }\end{array}$ & & & \\
\hline 1 (Constant) & 0.054 & 0.022 & & 2.474 & 0.015 \\
\hline ACHANGE & 0.025 & 0.009 & 0.292 & 2.787 & 0.006 \\
\hline LEV & -0.043 & 0.020 & -0.191 & -2.132 & 0.035 \\
\hline OSHIP & -0.017 & 0.041 & -0.036 & -0.416 & 0.678 \\
\hline ROA & -0.090 & 0.105 & -0.082 & -0.858 & 0.392 \\
\hline RECEIVABLE & 0.000 & 0.000 & -0.086 & -0.908 & 0.366 \\
\hline BDOUT & -0.006 & 0.010 & -0.055 & -0.609 & 0.544 \\
\hline $\mathrm{AO}$ & -0.003 & 0.007 & -0.035 & -0.409 & 0.683 \\
\hline $\mathrm{CPA}$ & -0.004 & 0.003 & -0.139 & -1.634 & 0.105 \\
\hline TATA & -0.003 & 0.023 & -0.013 & -0.128 & 0.899 \\
\hline DCHANGE & -0.001 & 0.002 & -0.065 & -0.751 & 0.454 \\
\hline
\end{tabular}

a. Dependent Variable:

ABS_RES1

Sumber : Data yang telah diolah (2019)
Setelah dilakukan transformasi data, hasil uji glejser memperoleh nilai berada diatas 0,05 sehingga dapat disimpulkan bahwa model regresi tidak mengandung adanya heterokedastisitas.

\section{Tabel 6}

Hasil Uji Glejser

(Setelah transformasi data)

\begin{tabular}{l|r|r|r|r|r}
\hline \multirow{2}{*}{ Model } & \multicolumn{2}{|c|}{$\begin{array}{c}\text { Unstandardized } \\
\text { Coefficients }\end{array}$} & $\begin{array}{l}\text { Standardized } \\
\text { Coefficients }\end{array}$ & \multirow{2}{*}{$\mathrm{t}$} & \multirow{2}{*}{ Sig. } \\
\cline { 2 - 4 } & \multicolumn{1}{c|}{ B } & $\begin{array}{c}\text { Std. } \\
\text { Error }\end{array}$ & \multicolumn{1}{c|}{ Beta } & & \\
\hline 1 (Constant) & 0.003 & 0.011 & & 0.231 & 0.818 \\
Ln_ACHANGE & -0.002 & 0.001 & -0.158 & -1.496 & 0.137 \\
Ln_LEV & -0.004 & 0.018 & -0.024 & -0.245 & 0.807 \\
OSHIP & -0.019 & 0.046 & -0.038 & -0.410 & 0.683 \\
ROA & -0.188 & 0.112 & -0.173 & -1.672 & 0.097 \\
RECEIVABLE & 0.000 & 0.000 & 0.163 & 1.685 & 0.095 \\
BDOUT & -0.005 & 0.011 & -0.047 & -0.480 & 0.632 \\
AO & 0.011 & 0.008 & 0.119 & 1.304 & 0.195 \\
CPA & 0.000 & 0.003 & -0.028 & -0.297 & 0.767 \\
TATA & -0.036 & 0.028 & -0.138 & -1.281 & 0.203 \\
DCHANGE & 0.000 & 0.002 & -0.017 & -0.188 & 0.851 \\
\hline
\end{tabular}

a. Dependent Variable: ABS_RES2

Sumber : Data yang telah diolah (2019)

Sedangkan, hasil pengujian heteroskedastisitas melalui scartterplot dapat dilihat pada gambar 2 (lihat lampiran) menunjukkan bahwa adanya titiktitik penyebaran secara acak dan tidak membentuk sebuah pola tertentu yang jelas. Penyebarannya pun nampak berada di atas dan di bawah angka nol pada sumbu Y. Maka hal ini menunjukan bahwa tidak terjadi heteroskedastisitas pada penelitian ini.

Tabel 7

Hasil Uji Multikolinearitas

\begin{tabular}{ll|r|r}
\hline \multirow{2}{*}{\multicolumn{1}{c|}{ Model }} & \multicolumn{2}{c}{ Collinearity Statistics } \\
\cline { 2 - 3 } 1 Ln_ACHANGE & Tolerance & \multicolumn{1}{c}{ VIF } \\
\hline Ln_LEV & 0.705 & 1.419 \\
OSHIP & 0.838 & 1.194 \\
ROA & 0.900 & 1.111 \\
RECEIVABLE & 0.731 & 1.369 \\
BDOUT & 0.832 & 1.202 \\
AO & 0.802 & 1.247 \\
CPA & 0.933 & 1.071 \\
TATA & 0.862 & 1.161 \\
DCHANGE & 0.677 & 1.477 \\
\hline
\end{tabular}

a. Dependent Variable: DAC

Sumber : Data yang telah diolah (2019) 


\section{Jurnal Akuntansi dan Pajak, 20(02), 2019, 119}

Hasil uji multikolinearitas menunjukkan bahwa semua variabel independen memiliki nilai tolerance lebih besar dari 0,10 dan nilai variance inflation factor (VIF) juga menunjukkan hal yang sama yaitu semua variabel independen memiliki nilai VIF lebih kecil dari 10. Maka dapat disimpulkan bahwa model regresi dalam penelitian ini telah memenuhi syarat multikolinearitas atau terbebas dari masalah multikolinearitas.

\section{Tabel 8}

Hasil Uji Autokorelasi

\begin{tabular}{c|c|r|r|r|r}
\hline Model & $\mathrm{R}$ & $\begin{array}{c}\mathrm{R} \\
\text { Square }\end{array}$ & $\begin{array}{r}\text { Adjusted } \\
\text { R Square }\end{array}$ & $\begin{array}{r}\text { Std. Error of } \\
\text { the Estimate }\end{array}$ & $\begin{array}{c}\text { Durbin- } \\
\text { Watson }\end{array}$ \\
\hline 1 & $.962^{\mathrm{a}}$ & .926 & .920 & .015931746 & 1.904 \\
\hline
\end{tabular}

a. Predictors: (Constant), DCHANGE, Ln_LEV, OSHIP, Ln_ACHANGE, CPA, AO, RECEIVABLE, BDOUT, ROA, TATA

b. Dependent Variable: DAC

Sumber : Data yang telah diolah (2019)

Berdasarkan hasil perhitungan pada tabel diatas nilai $d \mathrm{~W}$ diketahui sebesar 1,904 dengan nilai $d \mathrm{U}$ sebesar 1,898 dan nilai $d \mathrm{~L}$ adalah 1,462. Maka dapat disimpulkan apabila $d \mathrm{U}<d \mathrm{~W}<4-d \mathrm{U}$ artinya $\mathrm{H}_{0}$ diterima yang menyatakan bahwa tidak ada autokorelasi positif maupun negatif, atau dapata disimpulkan tidak terdapat autokorelasi dalam penelitian ini.

\section{Tabel 9}

Hasil Uji Pengaruh Simultan (Uji F)

\begin{tabular}{c|r|r|r|c|c}
\hline Model & $\begin{array}{c}\text { Sum of } \\
\text { Squares }\end{array}$ & df & $\begin{array}{c}\text { Mean } \\
\text { Square }\end{array}$ & F & Sig. \\
\hline 1 Regression & 0.372 & 10 & 0.037 & 146.726 & $.000^{\mathrm{a}}$ \\
Residual & 0.030 & 117 & 0.000 & & \\
Total & 0.402 & 127 & & & \\
\hline
\end{tabular}

a. Predictors: (Constant), DCHANGE, Ln_LEV,

OSHIP, Ln_ACHANGE, CPA, AO,

RECEIVABLE, BDOUT, ROA, TATA

b. Dependent Variable: DAC

Sumber : Data yang telah diolah (2019)

Berdasarkan tabel diatas dapat dilihat bahwa nilai signifikan adalah 0,000 dan dengan menentukan tingkat kesalahan 5\% derajat kebebasan $\mathrm{df}_{1}=10$ dan $\mathrm{df}_{2}=117$ maka diperoleh dari tabel $\mathrm{F}_{\text {tabel }}=1,91$. Oleh karena $\mathrm{F}_{\text {hitung }}>\mathrm{F}_{\text {tabel }}$ dan nilai signifikasi lebih kecil dari taraf signifikansi 0,05 Maka dapat disimpulkan bahwa variabel independen yaitu financial stability, financial target, external pressure, personal financial need, nature of industry, ineffective monitoring,auditor opinion, change in auditor, total akrual dan change in director secara simultan atau bersama-sama berperngaruh signifikan terhadap variabel dependen financial statement fraud.

Tabel 10

Hasil Uji Koefesien Determinasi (Adjusted $\mathbf{R}^{2}$ )

\begin{tabular}{c|c|r|r|r|r}
\hline Model & $\mathrm{R}$ & $\begin{array}{c}\mathrm{R} \\
\text { Square }\end{array}$ & $\begin{array}{r}\text { Adjusted } \\
\text { R Square }\end{array}$ & $\begin{array}{c}\text { Std. Error of } \\
\text { the Estimate }\end{array}$ & $\begin{array}{c}\text { Durbin- } \\
\text { Watson }\end{array}$ \\
\hline 1 & $.962^{\mathrm{a}}$ & .926 & .920 & .015931746 & 1.904 \\
\hline
\end{tabular}

a. Predictors: (Constant), DCHANGE, Ln_LEV, OSHIP, Ln_ACHANGE, CPA, AO, RECEIVABLE, BDOUT, ROA, TATA

b. Dependent Variable: DAC

Sumber : Data yang telah diolah (2019)

Berdasarkan hasil regresi pada tabel diatas dapat diketahui bahwa nilai adjusted $R^{2}$ sebesar 0,920 atau $92 \%$. Hal ini berarti $92 \%$ variasi financial statement fraud dapat dijelaskan oleh variabel financial stability, financial target, external pressure, personal financial need, nature of industry, ineffective monitoring, auditor opinion, change in auditor, total akrual dan change in director. Sisanya sebesesar $8 \%$ dijelaskan oleh faktor lain yang tidak disertakan dalam variabel penelitian ini.

Tabel 11

Hasil Uji Signifikansi

\begin{tabular}{l|r|r|r|r|c|}
\hline \multirow{2}{*}{ Model } & \multicolumn{2}{|c|}{$\begin{array}{c}\text { Unstandardized } \\
\text { Coefficients }\end{array}$} & $\begin{array}{r}\text { Standardized } \\
\text { Coefficients }\end{array}$ & \multirow{2}{*}{ Sig. } & Sig. \\
\cline { 2 - 5 } & \multicolumn{1}{c|}{ B } & $\begin{array}{c}\text { Std. } \\
\text { Error }\end{array}$ & Beta & & \\
\hline 1 (Constant) & -0.0395 & 0.016 & & -2.458 & 0.015 \\
Ln_ACHANGE & -0.0097 & 0.002 & -0.170 & -5.669 & $\mathbf{0 . 0 0 0}$ \\
Ln_LEV & -0.0002 & 0.025 & 0.000 & -0.008 & 0.994 \\
OSHIP & 0.1986 & 0.065 & 0.081 & 3.041 & $\mathbf{0 . 0 0 3}$ \\
ROA & 0.2783 & 0.158 & 0.052 & 1.761 & 0.081 \\
RECEIVABLE & -0.0022 & 0.000 & -0.169 & -6.134 & $\mathbf{0 . 0 0 0}$ \\
BDOUT & -0.0024 & 0.016 & -0.004 & -0.153 & 0.879 \\
AO & -0.0134 & 0.012 & -0.030 & -1.138 & 0.258 \\
CPA & -0.0035 & 0.004 & -0.021 & -0.782 & 0.436 \\
TATA & 1.0818 & 0.039 & 0.844 & 27.632 & $\mathbf{0 . 0 0 0}$ \\
DCHANGE & 0.0033 & 0.003 & 0.028 & 1.076 & 0.284 \\
\hline
\end{tabular}

a. Dependent Variable: DAC

Sumber : Data yang telah diolah (2019)

Hubungan antara variabel independen terhadap variabel dependen secara parsial dapat dijelaskan sebagai berikut :

a. Variabel financial stability (ACHANGE), external pressure (OSHIP), nature of industry (RECEIVABLE) dan total akrual (TATA) memiliki nilai signifikansi lebih kecil dari taraf signifikansi $(0,05)$ yang berarti bahwa variabelvariabel tersebut signifikan terhadap financial statement fraud. 


\section{Jurnal Akuntansi dan Pajak, 20(02), 2019, 120}

b. Variabel financial target (LEV), personal financial need (ROA), ineffective monitoring (BDOUT), auditor opinion (AO), change in auditor (CPA), dan change in director (DCHANGE) memiliki nilai signifikansi lebih besar dari taraf signifikansi $(0,05)$ yang berarti bahwa variabel-variabel tersebut tidak signifikan terhadap financial statement fraud.

\subsection{Pembahasan}

$$
\begin{aligned}
\mathrm{DAC}_{\mathrm{it}}= & -0,0395-0,0097 \mathrm{ACHANGE}-0,0002 \mathrm{LEV} \\
& +0,1986 \mathrm{OSHIP}-0,2783 \mathrm{ROA}- \\
& 0,0022 \mathrm{RECEIVABLE}-0,0024 \mathrm{BDOUT}- \\
& 0,0134 \mathrm{AO}-0,0035 \Delta \mathrm{CPA}+1,0818 \mathrm{TATA} \\
& +0,0033 \mathrm{DCHANGE}+\varepsilon
\end{aligned}
$$

Menurut persamaan regresi di atas dapat dijelaskan pengaruh variabel financial stability, financial target, external pressure, personal financial need, nature of industry, ineffective monitoring, auditor opinion, change in auditor, total akrual dan change in director terhadap variabel financial statement fraud adalah sebagai berikut :

\section{a) Pengaruh Pressure dengan kategori \\ Financial Stability terhadap Financial Statement Fraud}

Pengujian hipotesis pertama $\left(\mathrm{H}_{1}\right)$ menunjukkan variabel financial stability (ACHANGE) terhadap probabilitas suatu perusahaan melakukan tindakan financial statement fraud diperoleh koefesien 0,0097 artinya setiap pertambahan $1 \%$ pada rasio perubahan aset akan menurunkan risiko financial statement fraud sebesar 0,0097 satuan dengan nilai signifikansi sebesar 0,000. Hasil uji hipotesis ini menunjukkan financial stability (ACHANGE) tidak berpengaruh positif dan signifikan terhadap financial statement fraud, sehingga variabel tersebut tidak dapat digunakan untuk mendeteksi kecurangan laporan keuangan. Hal ini berarti bahwa hipotesis pertama $\left(\mathrm{H}_{1}\right)$ ditolak.

Hasil penelitian ini sejalan dengan penelitian Yesiariani dan Rahayu (2016) yang menunjukkan bahwa financial stability (ACHANGE) berpengaruh negatif dan signifikan terhadap financial statement fraud, karena perusahaan sampel memiliki persentase perubahan total aset yang tidak signifikan artinya stabilitas keuangan atau profitabilitas perusahaan berkembang di atas rata-rata industri. Hal ini disebabkan beberapa kemungkinan, yaitu adanya perkembangan aset, dana pihak ketiga dan kredit di sektor perbankan mengalami kenaikan selama tahun 2014 - 2018. Selain itu, tingkat pengawasan Dewan Komisaris yang sangat baik untuk memonitor dan mengendalikan manajemen perusahaan sehingga walaupun manajemen menghadapi tekanan ketika stabilitas keuangan terancam oleh keadaan ekonomi, industri dan situasi entitas yang beroperasi tidak akan mempengaruhi terjadinya kecurangan laporan keuangan.

Penelitian ini bertentangan dengan penelitian Sihombing dan Raharjo (2014), Skousen,et al. (2009) dan Aprilia (2017) yang menunjukkan bahwa financial stability (ACHANGE) berpengaruh positif signifikan terhadap kecenderungan terjadi kecurangan laporan keuangan.

b) Pengaruh Pressure dengan kategori External
Pressure terhadap Financial Statement Fraud

Pengujian hipotesis kedua $\left(\mathrm{H}_{2}\right)$ menunjukkan variabel external pressure (LEV) terhadap probabilitas suatu perusahaan melakukan tindakan financial statement fraud diperoleh koefesien 0,0002 artinya setiap pertambahan $1 \%$ pada rasio total kewajiban terhadap total aset akan menurunkan risiko financial statement fraud sebesar 0,0002 satuan dengan nilai signifikansi sebesar 0,994. Hasil uji hipotesis ini menunjukkan external pressure (LEV) tidak berpengaruh dan tidak signifikan terhadap financial statement fraud, sehingga variabel tersebut tidak dapat digunakan untuk mendeteksi kecurangan laporan keuangan. Hal ini berarti bahwa hipotesis kedua $\left(\mathrm{H}_{2}\right)$ ditolak.

Hasil penelitian ini sependapat dengan Oktarigusta (2017) dan Hanifa dan Laksito (2015) bahwa leverage tidak berpengaruh signifikan terhadap kecurangan laporan keuangan. Hal ini dikarenakan perusahaan memiliki kemampuan untuk membayar utang-utangnya sehingga tidak menjadi tekanan bagi manajemen perusahaan untuk mencari tambahan modal selain dengan perjanjian utang. Prajanto (dalam Rahmanti dkk, 2013) berpendapat bahwa banyak perusahaan yang memilih menerbitkan saham kembali untuk memperoleh tambahan modal usaha tanpa harus melakukan perjanjian utang baru yang menyebabkan beban utang perusahaan dan nilai leverage perusahaan semakin rendah.

Namun, penelitian ini berbeda dengan penelitian Sihombing dan Raharjo (2014), Skousen, et al. (2009) dan Yesiariani dan Rahayu (2016) yang menunjukkan bahwa external pressure (LEV) berpengaruh signifikan terhadap kecenderungan terjadi kecurangan laporan keuangan. 


\section{Jurnal Akuntansi dan Pajak, 20(02), 2019, 121}

c) Pengaruh Pressure dengan kategori Personal Financial Need terhadap Financial Statement Fraud

Pengujian hipotesis ketiga $\left(\mathrm{H}_{3}\right)$ menunjukkan variabel personal financial need (OSHIP) terhadap probabilitas suatu perusahaan melakukan tindakan financial statement fraud diperoleh koefesien 0,1986 artinya setiap pertambahan $1 \%$ pada rasio kepemilikan saham oleh orang dalam akan menaikan risiko financial statement fraud sebesar 0,1986 satuan dengan nilai signifikansi sebesar 0,003.

Hasil uji hipotesis ini menunjukkan bahwa personal financial need (OSHIP) berpengaruh positif dan signifikan terhadap financial statement fraud, sehingga variabel tersebut dapat digunakan untuk mendeteksi kecurangan laporan keuangan. Hal ini berarti bahwa hipotesis ketiga $\left(\mathbf{H}_{3}\right)$ diterima. Namun, hasil penelitian ini tidak sependapat dengan Yesiariani (2016) dan Regina (2017) yang menunjukkan bahwa personal financial need (OSHIP) tidak berpengaruh dan tidak signifikan terhadap kecenderungan terjadi kecurangan laporan keuangan.

Kepemilikan saham oleh manajer, direktur maupun komisaris pada perusahaan berpengaruh terhadap kebijakan manajerial yang diterapkan perusahaan. Oleh karena itu, penelitian ini sesuai dengan hasil penelitian Nugraheni (2017) dan Skousen,et al. (2009) bahwa semakin besar rasio kepemilikan saham oleh pihak internal perusahaan maka semakin besar kesempatan manajemen untuk melakukan kecurangan. Hal ini disebabkan karena manajemen memiliki peran ganda sebagai pelaksana sekaligus sebagai pemilik, sehingga memudahkan melakukana tindakan kecurangan melalui pencapaian performa tertentu untuk memperoleh deviden dan return saham yang tinggi.

\section{d) Pengaruh Pressure dengan kategori Financial Target terhadap Financial Statement Fraud}

Pengujian hipotesis keempat $\left(\mathrm{H}_{4}\right)$ menunjukkan variabel financial target (ROA) terhadap probabilitas suatu perusahaan melakukan tindakan financial statement fraud diperoleh koefesien 0,2783 artinya setiap pertambahan $1 \%$ pada rasio yang digunakan untuk mengukur kemampuan perusahaan menghasilkan laba setelah pajak akan menaikan risiko financial statement fraud sebesar 0,2783 satuan dengan nilai signifikansi sebesar 0,081. Hasil uji hipotesis ini menunjukkan financial target (ROA) berpengaruh positif dan tidak signifikan terhadap financial statement fraud, sehingga variabel tersebut tidak dapat digunakan untuk mendeteksi kecurangan laporan keuangan. Hal ini berarti bahwa hipotesis keempat $\left(\mathrm{H}_{4}\right)$ ditolak.

Penelitian ini memiliki hasil yang berbeda dengan penelitian Sihombing dan Raharjo (2014), Yesiariani dan Rahayu (2016), serta Putriasih dkk. (2016) menunjukkan bahwa financial target berpengaruh positif dan signifikan terhadap financial statement fraud. Meskipun manajer dituntut untuk bisa mencapai target keuangan yang telah direncanakan agar dapat menarik investor melalui nilai ROA yang tinggi, namun tidak menjadikan manajemen melakukan manajemen laba. Hal ini berkaitan dengan adanya peraturan dari Otoritas Jasa Keuangan(OJK) yang berkaitan dengan fraud, yaitu Peraturan OJK No.18/POJK.03/2016 dan Surat Edaran OJK No.34/SEOJK.03/2016 tentang Penerapan Manajemen Risiko bagi Bank Umum. Apabila diketahui manajemen melakukan kecurangan untuk memenuhi target keuangan yang ditetapkan, maka terdapat sanksi pidana sebagai konsekuensi atas tindakan tersebut.

Selain itu, kenaikan profitabilitas perusahaan dapat diperoleh melalui peningkatan mutu operasional perusahaan seperti modernisasi sistem informasi, perekrutan tenaga kerja yang potensial serta kebijakan direksi yang tepat dalam menyelesaikan masalah. Hal ini sependapat dengan hasil penelitian Sihombing dan Raharjo (2014), Puspitadewi dan Sormin (2017), serta Annisya dkk (2016) bahwa financial target (ROA) tidak berpengaruh terhadap indikasi adanya kecurangan dalam laporan keuangan.

\section{e) Pengaruh faktor risiko Opportunity dengan kategori Nature of Industry terhadap Financial Statement Fraud}

Pengujian hipotesis kelima $\left(\mathrm{H}_{5}\right)$ menunjukkan variabel nature of industry (RECEIVABLE) terhadap probabilitas suatu perusahaan melakukan tindakan financial statement fraud diperoleh koefesien $-0,0022$ artinya setiap pertambahan $1 \%$ pada rasio piutang terhadap penjualan akan menurunkan risiko financial statement fraud sebesar 0,0022 satuan dengan nilai signifikansi sebesar 0,000 . Hasil uji hipotesis ini menunjukkan nature of industry (RECEIVABLE) tidak berpengaruh positif dan signifikan terhadap financial statement fraud, sehingga variabel tersebut tidak dapat digunakan untuk mendeteksi kecurangan laporan keuangan. Hal ini berarti bahwa hipotesis kelima $\left(\mathbf{H}_{5}\right)$ ditolak. 


\section{Jurnal Akuntansi dan Pajak, 20(02), 2019, 122}

Hasil penelitian ini sesuai dengan penelitian Nugraheni dan Triatmoko (2017) serta Yesiariani dan Rahayu (2016) yang menyatakan bahwa nilai rata-rata perubahan piutang perusahaan tidak berpengaruh terhadap terhadap perputaran kas perusahaan sehingga rasio perubahan dalam piutang tidak memicu manajemen untuk melakukan kecurangan laporan keuangan. Hal ini disebabkan sampel penelitian ini merupakan perusahaan perbankan dengan kecenderungan memiliki nilai piutang yang besar dan mengalami peningkatan setiap tahunnya disebabkan adanya tugas dan fungsi perbankan untuk memberikan kredit kepada masyarakat.

Berbeda halnya dengan penelitian yang dikemukakan oleh Sihombing (2014) dan Putriasih (2016) yang menunjukan bahwa presentase perubahan total piutang pada penjualan berpengaruh positif terjadi kecurangan dalam laporan keuangan melalui account piutang.

f) Pengaruh faktor risiko Opportunity dengan kategori Ineffective Monitoring terhadap Financial Statement Fraud

Pengujian hipotesis keenam $\left(\mathrm{H}_{6}\right)$ menunjukkan variabel ineffective monitoring (BDOUT) terhadap probabilitas suatu perusahaan melakukan tindakan financial statement fraud diperoleh koefesien 0,0024 artinya setiap pertambahan $1 \%$ pada rasio komisaris yang berasal dari luar perusahaan terhadap keseluruhan anggota dewan komisaris akan menurunkan risiko financial statement fraud sebesar 0,0024 satuan dengan nilai signifikansi sebesar 0,879. Hasil uji hipotesis ini menunjukkan ineffective monitoring (BDOUT) tidak berpengaruh positif dan tidak signifikan terhadap financial statement fraud, sehingga variabel tersebut tidak dapat digunakan untuk mendeteksi kecurangan laporan keuangan. Hal ini berarti bahwa hipotesis keenam $\left(\mathbf{H}_{6}\right)$ ditolak.

Hasil temuan ini berbeda dengan penelitian yang dilakukan oleh Aprilia (2017) dan Putriasih (2016) menunjukkan bahwa ineffective monitoring dari variabel opportunity memiliki pengaruh positif dan signifikan terhadap kecenderungan terjadi kecurangan dalam laporan keuangan. Namun, hasil penelitian ini konsisten dengan Sihombing dan Raharjo (2014), Yesiariani dan Rahayu (2016), serta Nugraheni dan Triatmoko (2017) yang berpendapat bahwa ineffective monitoring (BDOUT) tidak berpengaruh secara signifikan terhadap kecurangan dalam laporan keuangan.
Komposisi dan jumlah dewan komisaris dalam perbankan di Indonesia telah diatur oleh Otoritas Jasa Keuangan No. 55/POJK.03/2016 tentang Penerapan Tata Kelola bagi Bank Umum yang menyatakan bahwa susunan dewan komisaris mewajibkan paling sedikit $50 \%$ anggota dewan komisaris harus diduduki oleh dewan komisaris independen. Hal inilah yang mempengaruhi mekanisme pengawasan dalam perusahaan. Pengawasan dari Bank Indonesia melalui OJK juga dilakukan setiap tahun, sehingga pengawasan terhadap perbankan saat ini sangat ketat untuk meminimalkan ketidakefektifan pengawasan.

\section{g) Pengaruh faktor risiko Rationalization dengan kategori Opinion Auditor terhadap Financial Statement Fraud}

Pengujian hipotesis ketujuh $\left(\mathrm{H}_{7}\right)$ menunjukkan variabel auditor opinion (AO) terhadap probabilitas suatu perusahaan melakukan tindakan financial statement fraud diperoleh koefesien -0,0134 artinya setiap pertambahan $1 \%$ pada perusahaan yang mendapat opini wajar tanpa pengecualian dengan bahasa penjelas akan menurunkan risiko financial statement fraud sebesar 0,0134 satuan dengan nilai signifikansi sebesar 0,258. Hasil uji hipotesis ini menunjukkan auditor opinion (AO) tidak berpengaruh positif dan tidak signifikan terhadap financial statement fraud, sehingga variabel tersebut tidak dapat digunakan untuk mendeteksi kecurangan laporan keuangan. Hal ini berarti bahwa hipotesis ketujuh $\left(\mathrm{H}_{7}\right)$ ditolak.

Penelitian ini mendukung penelitian Fimanaya dan Safrudin (2014), dan Annisya dkk (2016) menyatakan bahwa opini wajar tanpa pengecualian dengan bahasa penjelas berpengaruh negatif dan tidak signifikan terhadap kemungkinan kecurangan pada laporan keuangan. Hal ini dikarenakan laporan auditor independen pada sampel yang diteliti bahwa auditor menyatakan penambahan bahasa penjelas ini tidak mempengaruhi materialitas dalam laporan keuangan, serta tidak mengubah kewajaran dari laporan keuangan itu sendiri. Oleh karena itu, penambahan bahasa penjelas ini tidak mempengaruhi kemungkinan kecurangan yang dilakukan oleh manajemen perusahaan.

\section{h) Pengaruh faktor risiko Rationalization dengan kategori Change in Auditor terhadap Financial Statement Fraud}

Pengujian hipotesis kedelapan $\left(\mathrm{H}_{8}\right)$ menunjukkan variabel change in auditor ( $\triangle C P A)$ terhadap probabilitas suatu perusahaan melakukan 
tindakan financial statement fraud diperoleh koefesien $-0,0035$ artinya setiap pertambahan $1 \%$ pada kemungkinan perusahaan melakukan pergantian auditor menurunkan risiko financial statement fraud sebesar 0,0035 satuan dengan nilai signifikansi sebesar 0,436. Hasil uji hipotesis ini menunjukkan change in auditor ( $\triangle C P A)$ tidak berpengaruh positif dan tidak signifikan terhadap financial statement fraud, sehingga variabel tersebut tidak dapat digunakan untuk mendeteksi kecurangan laporan keuangan. Hal ini berarti bahwa hipotesis kedelapan $\left(\mathrm{H}_{8}\right)$ ditolak.

Hasil temuan ini sesuai dengan penelitian Sihombing dan Raharjo (2014), Yesiariani dan Rahayu (2016),serta Kusumaningrum dan Murtanto (2016) yang berpendapat bahwa change in auditor tidak berpengaruh terhadap financial statement fraud. Hal tersebut disebabkan kemungkinan perusahaan melakukan pergantian auditor bukan karena menghindari pendeteksian laporan keuangan dari auditor lama, namun karena perusahaan melaksanakan Peraturan Pemerintah Republik Indonesia No. 20 tahun 2015 pasal 11 ayat 1 yang menyatakan bahwa pemberian jasa audit atas laporan keuangan terhadap suatu entitas oleh Akuntan Publik dibatasi paling lama 5 (lima) tahun buku berturutturut.

Penelitian ini bertolakbelakang dengan hasil penelitian Skousen, et al. (2009) dan Putriasih (2016) yang berhasil membuktikan bahwa pergantian auditor dapat digunakan untuk mendeteksi financial statement fraud. Semakin sering terjadi pergantian auditor, maka semakin tinggi pula kemungkinan terjadinya laporan keuangan.

i) Pengaruh faktor risiko Rationalization dengan kategori Total Akrual terhadap Financial Statement Fraud

Pengujian hipotesis kesembilan menunjukkan variabel Total Akrual to Total Asset (TATA) terhadap probabilitas suatu perusahaan melakukan tindakan financial statement fraud diperoleh koefesien 1,0818 artinya setiap pertambahan $1 \%$ pada rasio total akrual akan menaikan risiko financial statement fraud sebesar 1,0818 satuan dengan nilai signifikansi sebesar 0,000. Hasil uji hipotesis ini menunjukkan Total Akrual to Total Asset (TATA) berpengaruh positif dan signifikan terhadap financial statement fraud, sehingga variabel tersebut dapat digunakan untuk mendeteksi kecurangan laporan keuangan. Hal ini berarti bahwa hipotesis kesembilan $\left(\mathbf{H}_{9}\right)$ diterima.
Konsisten dengan penelitian yang dilakukan oleh Oktarigusta (2017), Putriasih (2016), dan Sihombing (2014) menunjukkan bahwa proksi total aset akrual dari variabel rationalization memiliki pengaruh positif dan signifikan terhadap financial statement fraud karena konsep akrual yang berarti manajemen dapat memanipulasi pendapatan dengan melakukan pencatatan ketika transaksi terjadi meskipun kas belum melakukan pengeluaran atau penerimaan, sehingga jika nilai discretionary accruals naik, dapat disimpulkan kecurangan laporan keuangan juga naik.

Rasionalisasi erat kaitannya dengan penilaianpenilaian subyektif perusahaan. Penilaian dan pengambilan keputusan perusahaan yang subyektif tersebut akan tercermin dari nilai akrual perusahaan (Skousen, et al. (2009). Walaupun demikian hasil penelitian ini tidak mendukung hasil temuan Skousen, et al. (2009) yang menunjukkan bahwa rasio total akrual tidak berpengaruh terhadap financial statement fraud, karena rasionalisasi merupakan unsur yang paling sulit untuk mengindikasi pengukurannya.

j) Pengaruh faktor risiko Capability dengan
kategori Change In Director terhadap
Financial Statement Fraud

Pengujian hipotesis kesepuluh $\left(\mathrm{H}_{10}\right)$ menunjukkan variabel change in director (DCHANGE) terhadap probabilitas suatu perusahaan melakukan tindakan financial statement fraud diperoleh koefesien 0,0033 artinya setiap pertambahan $1 \%$ pada kemungkinan perubahan direksi perusahaan akan menaikan risiko financial statement fraud sebesar 0,0033 satuan dengan nilai signifikansi sebesar 0,284. Hasil uji hipotesis ini menunjukkan change in director (DCHANGE) berpengaruh positif dan tidak signifikan terhadap financial statement fraud, sehingga variabel tersebut tidak dapat digunakan untuk mendeteksi kecurangan laporan keuangan. Hal ini berarti bahwa hipotesis kesepuluh $\left(\mathrm{H}_{10}\right)$ ditolak.

Hasil temuan ini sesuai dengan penelitian Sihombing dan Raharjo (2014), Yesiariani dan Rahayu (2016), serta Nugraheni dan Triatmoko (2017) yang menyatakan bahwa perubahan direksi tidak memiliki pengaruh signifikan terhadap financial statement fraud. Hasil penelitian ini mengindikasikan bahwa tingkat pergantian direksi tidak memicu untuk melakukan kecurangan laporan keuangan karena adanya pengawasan yang efektif dari dewan komisaris terhadap kinerja manajemen. 


\section{Jurnal Akuntansi dan Pajak, 20(02), 2019, 124}

Selain itu, terdapat perubahan direksi disebabkan adanya pengunduran diri atau direksi sebelumnya meninggal dunia sehingga untuk mengisi kekosongan posisi tersebut perusahaan melakukan perubahan pada susunan dewan direksi.

Jadi, dapat disimpulkan bahwa perusahaan yang melakukan perubahan direksi bukan karena perusahaan ingin menutupi kecurangan yang dilakukan direksi sebelumnya, melainkan karena perusahaan menginginkan adanya perbaikan kinerja perusahaan dengan cara merekrut direksi yang dianggap lebih kompeten dibandingkan direksi sebelumnya.

Hasil penelitian ini bertentangan dengan penelitian yang dilakukan Wolfe dan Hermanson (2004), serta Putriasih (2016) menunjukkan bahwa perubahan direksi berpengaruh positif dan signifikan terhadap indikasi adanya financial statement fraud karena perubahan direksi dianggap sebagai upaya perusahaan untuk menyingkirkan direksi yang dianggap mengetahui adanya kecurangan yang dilakukan perusahaan.

\section{Kesimpulan}

Berdasarkan hasil penelitian dan pembahasan, maka dapat diperoleh kesimpulan sebagai berikut (1) Financial stability (ACHANGE) dan nature of industry (RECEIVABLE) tidak berpengaruh positif dan signifikan terhadap financial statement fraud. (2) Personal financial need (OSHIP) dan Total Akrual to Total Asset (TATA) berpengaruh positif dan signifikan terhadap financial statement fraud.(3) Financial target (ROA) dan change in director (DCHANGE) berpengaruh positif dan tidak signifikan terhadap financial statement fraud.(4) External pressure (LEV), ineffective monitoring (BDOUT), auditor opinion (AO) dan change in auditor ( $\triangle C P A$ ) tidak berpengaruh positif dan tidak signifikan terhadap financial statement fraud.

Penelitian ini memiliki sejumlah keterbatasan, antara lain (1) Penelitian ini hanya mengambil sampel pada satu jenis subsektor industri saja yang terdaftar di BEI Indonesia yaitu perusahaan sektor keuangan subsektor perbankan. (2) Penelitian ini menggunakan metode kuantitatif dalam pengukuran dan analisis variabel-variabelnya, sehingga diasumsikan setiap variabel mendapat bobot yang sama.(3) Penelitian ini mengukur financial statement fraud dengan menggunakan nilai discretionary accrual dari earning management. (4) Periode pengamatan hanya dalam periode singkat yaitu 5 tahun, mulai dari tahun 2014-2018.

Berdasarkan keterbatasan yang telah dijelaskan di atas, maka peneliti memberikan saran sebagai berikut (1) Penelitian selanjutnya dapat memperluas area sampel penelitian agar dapat menganalisis financial statement fraud secara menyeluruh. (2) Penelitian selanjutnya terkait fraud diamond dan financial statement fraud dapat menggunakan metode kualitatif, atau dengan mengkombinasikan metode kualitatif dengan metode kuantitatif. Kelemahan atau bias statistikt yang terjadi sebagai dampak penggunaan metode kuantitatif, karena terdapat variabel yang tidak dapat dijelaskan dengan spesifik oleh alat analisis metode kuantitatif, yaitu variabel rationalization dan capability. (3) Penelitian selanjutnya dapat menggunakan pengukuran financial statement fraud selain discretionary accrual agar dapat memberikan alternatif dan perbandingan untuk meningkatkan kualitas penelitian-penelitian selanjutnya.(4) Penelitian selanjutnya untuk memperpanjang waktu pengamatan agar hasil penelitian dapat lebih akurat.

\section{Daftar Pustaka}

American Institute of Certified Public Accountants (AICPA). 2002. "Consideration of Fraud in a Financial Statement Audit." Statement on Auditing Standards No. 99. New York, NY: AICPA.

Aprilia, R. 2017, Pengaruh Financial Stability, Personal Financial Need, Ineffective Monitoring, Change in Auditor dan Change In Director terhadap Financial Statement Fraud dalam Perspektif Fraud Diamond (Studi Empiris pada Perusahaan Manufaktur yang Terdaftar di BEI periode 2012-2014). JOM Fekon Vol.4 No.1

Association of Certified Fraud Examiners (ACFE). 2016. Report to Nation. Diambil dari http://www.acfe.com/rttn2016/images/fraudtree.jpg

Beasley, M. (1996). An empirical analysis of the relation between the board of director composition and financial statement fraud. The Accounting Review, 71(4)

Cressey, D. 1953. Other people's money, dalam: The Internal Auditor as Fraud buster, Hillison, William. et. al. 1999. Managerial Auditing Journal, MCB University Press 


\section{Jurnal Akuntansi dan Pajak, 20(02), 2019, 125}

Dalnial, Hawariah. et al. 2014. Detecting Fraudulent Financial Reporting through Financial Statement Analysis. Journal of Advanced Management Science Vol. 2, No. 1

DeAngelo,L.E. 1986. Accounting Numbers as Market Valuation Substitutes: A Study of Management Buyouts of Public Stockholders. The Accounting Review, 61

Dunn. P. (2004). The impact of insider power on fraudulent financial reporting. Journal of Management, 30(3)

Fimanaya, F dan Syafruddin, M. 2014. Analisis Faktor-Faktor yang Mempengaruhi Kecurangan laporan Keuangan (Studi Empiris pada Perusahaan Non Keuangan yang Terdaftar di Bursa Efek Indonesia Tahun 2008-2011). Diponegoro Journal of Accounting Vol. 03 No. 03

Ghozali, Imam. 2013. Aplikasi Analisis Multivariate dengan Program IBM SPSS 21 Update PLS Regresi : Edisi 7. Badan Penerbit Universitas Diponegoro

Hall, James, A. 2001. Sistem Informasi Akuntansi. Alih Bahasa Thomson Learning Asia. Jakarta. Penerbit: Salemba Empat

Ikatan Akuntan Indonesia. 2001. Standar Profesional Akuntan Publik. Jakarta: Salemba Empat

Khrisnan,G.V. 2003. Audit Quality and The Pricing of Discretionary Accruals. Auditing: A Journal of Practice and Theory, 22(1)

Nugraheni, N.K. dan Triatmoko. H. 2017. Analisis Faktor-Faktor yang Mempengaruhi Terjadinya Financial Statement Fraud : Perspektif Diamond Fraud Theory (Studi pada Perusahaan Perbankan yang Terdaftar di BEI Periode 20142016). Jurnal Akuntansi dan Auditing Vol. 14 No. 2

Puspitadewi, E. dan Sormin, P. 2017. Pengaruh Fraud Diamond Dalam Mendeteksi Financial Statement Fraud (Studi Pada Perusahaan Manufaktur Yang Terdaftar Di Bursa Efek Indonesia Tahun 2014-2016). Jurnal Akuntansi Unika Atmajaya Vol. 12 No.2
Putriasih, K., Herawati, N. T., Wahyuni, M.A. 2016. Analisis Fraud Diamond dalam Mendeteksi Financial Statement Fraud : Studi Empiris pada Perusahaan Manufaktur yang Terdaftar di BEI tahun 2013-2015. Jurnal Akuntansi Program S1 Universitas Pendidikan Ganesha Vol. 6 No. 3

Rahmanti, Martantya, dan Daljono. 2013. Pendeteksian Kecurangan Laporan Keuangan Melalui Faktor Risiko Tekanan Dan Peluang (Studi Kasus Pada Perusahaan Yang Mendapat Sanksi Dari Bapepam Periode 2002-2006). Jurnal Akuntansi Fakultas Ekonomika Dan Bisnis Universitas Diponegoro 2 (2): 1-12.

Rezaee, Z. 2002. Financial Statement Fraud:Prevention and Detection. New York : John Wiley \& Sons Inc.

Sihombing, K.S. dan Raharjo, S. N. 2014. Analisis Fraud Diamond dalam Mendeteksi Financial Statement Fraud : Studi Empiris pada Perusahaan Manufaktur yang Terdaftar di BEI tahun 2010-2012. Diponegoro Journal of Accounting Vol.03 No.02

Skousen, J.C., Wright, J.C., Smith Kevin, R. 2009, "Detecting and Predicting Financial Statement Fraud: The Effectiveness of The Fraud Triangle and SAS No. 99." Advances in Financial Economics, Vol. 13

Soltani, Bahram. 2014. Anatomy of Corporate Fraud: A Comparative Analysis of High Profile American and European Corporate Scandals. Journal of Business Ethics 120:251-274

Wells, Joseph, T. 2011. Principles of Fraud Examination : Third Edition. John Wiley and Sons. New Jersey

Wolfe, D., and Hermanson, D. R. 2004. The Fraud Diamond: Considering Four Elements of Fraud. The CPA Journal. Volume 74, No. 12

Yesiariani, M. dan Rahayu, I. 2016. Analisis Fraud Diamond dalam Mendeteksi Financial Statement Fraud : Studi Empiris pada Perusahaan LQ-45yang Terdaftar di BEI tahun 2010-2014" Simposium Nasional Akuntansi XIX Lampung. 